\title{
PEMANFAATAN TANAMAN refugia MENGENDALIKAN HAMA PADI (Oryza nivara L) DI SOPORARU TAPANULI UTARA
}

\author{
Sampe Lesnida ${ }^{1 *}$, Darma Bakti ${ }^{2}$, Amelia Zuliyanti Siregar ${ }^{3 *}$ \\ ${ }^{1,2,3}$ Agroteknologi, Fakultas Perrtanian Universitas Sumatera Utara \\ Jalan Dr Mansyur No 9 Padang Bulan Kec Medan Baru, Medan 20222 \\ *Email : ameiliazuliyanti@gmail.com, lesnidasampe20@gmail.com
}

\begin{abstract}
ABSTRAK
Pemanfaatan Tanaman refugia Mengendalikan Hama Padi (Oryza nivara L) Di Soporaru Tapanuli Utara.

Tanaman refugia salah satu bunga yang dapat dijadikan sebagai tempat perlindungan bagi musuh alami serta sebagai sumber makanan bagi serangga. Tujuan penelitian ini adalah untuk mengetahui pemanfaatan tanaman refugia dan tanpa refugia dalam mengendalikan hama padi merah Natabo Natabo ramah lingkungan di Dusun Soporaru, Desa Sigotom Julu, Kecamatan Pangaribuan, Kabupaten Tapanuli Utara, Provinsi Sumatera Utara. Penelitian ini menggunakan metode purposive sampling dengan 3 jenis perangkap (perangkap kuning, perangkap jatuh dan perangkap jaring). Sampel yang diperoleh dibawa dan diidentifikasi di Laboratorium Penyakit Tanaman, Fakultas Pertanian, Universitas Sumatera Utara pada Juli 2020 sampai Februari 2021. Hasil penelitian menunjukkan Arthropoda yang tertangkap pada lahan menggunakan refugia didentifikasi sebanyak 8 ordo, 23 famili, dan 1952 ekor sedangkan pada lahan tanpa refugia sebanyak 8 ordo, 22 famili dan 1807 ekor. Pada lahan menggunakan refugia (r) dibandingkan dengan lahan tanpa refugia (k) diketahui Indeks Kekayaan Jenis (R) ( $R r=2,9$ dan $R k=2,8)$, Indeks Keanekaragaman $\left(H^{\prime}\right)\left(H^{\prime} r=2,67\right.$ dan $\left.H^{\prime} k=2,19\right)$, dan Indeks Kemerataan $(\mathrm{E})(\mathrm{Er}=0,85$ dan $\mathrm{Ek}=0,71)$. Status fungsi teridentifikasi pada lahan menggunakan refugia dan tanpa refugia di padi terdeteksi sebanyak 5 katrgori, yaitu herbivor, polinator, predator, parasitoid dan scavenger.
\end{abstract}

Kata kunci : Herbivora, polinator, parasitoid, predator, scavenger.

\section{ABSTRACT}

The Utilization Of Plant Refugia In Controlling Pests Of Rice (Oryza Nivara L) In Soporaru Tapanuli Utara.

The refugia plant is one of the flowers that can be used as a refugia for natural enemies and as a feed sources for insects. The purpose of this study was to compare the use of refugia and without refugia plants in controlling environmentally friendly red rice pests in Soporaru Hamlet, Sigotom JuluVilalge, Pangaribuan District, North of Tapanuli Regency, North of Sumatra Province. This study used purposive sampling methods with 3 types of traps (yellowsticky traps, pit fall traps and net traps). The samples was identified in the Plant Disease Laboratory, Faculty of Agriculture, University of North Sumatra in July 2020 until February 2021. The results showed that 8 orders of refugia were caught on land using refugia, 23 families, and 1,952 individuals, while on land without refugia there were 8 orders, 22 families and 1,807 individuals. On land using refugia $(r)$ compared to land without refugia $(k)$ it is known that the Species Richness Index $(R)(R r=2.9$ and $R k=2.8)$, Diversity Index $(H)(H r=2.67$ and $H k=2.19)$, and Evenness Index $(E)(E r=0.85$ and Ek=0.71). The status of functions identified on land using refugia and without refugia as many as 5 species, namely herbivores, pollinators, predators, parasitoids and scavengers.

Keywords: Herbivore, Parasitoid, Polinator, Predator, Scavenger.

\section{PENDAHULUAN}

Salah satu cara yang dapat digunakan untuk mempertahankan keanekaragaman hayati karena dampak negative penggunaan bahan kimia yaitu dengan cara memanfaatkan tumbuhan berbunga yang pada pematang sawah.
Tanaman refugia salah satunya bunga dapat dijadikan sebagai tempat perlindungan bagi musuh alami serta sebagai penyedia pakan (Erdiansyah et dkk., 2018).

Tumbuhan berbunga menarik kedatangan serangga menggunakan 
karakter morfologi dan fisiologi dari bunga, yaitu ukuran, bentuk, warna, keharuman, periode berbunga, serta kandungan nektar dan polen. Kebanyakan dari serangga lebih menyukai bunga yang berukuran kecil, cenderung terbuka, dengan waktu berbunga yang cukup lama yang biasanya terdapat pada bunga dari famili Compositae atau Asteraceae (Erdiyansyah, 2017).

refugia adalah mikrohabitat yang menyediakan tempat berlindung secara spasial dan/atau temporal bagi musuh alami hama, seperti predator dan parasitoid, serta mendukung komponeni nteraksi biotik pada ekosistem, seperti pollinator atau serangga penyerbuk (Keppel dkk, 2012).

Bagi tanaman padi refugia dapat mendukung kegiatan konservasi sebagai pilihan dalam menjaga agroekosistem pada lahan pertanian refugia dengan warna mencolok merupakan tanaman yang mudah dibudidayakan sebagai tempat mikrohabitat serta organisme tertentu. Pada ekosistem lahan pertanian, keberadaan mikrohabitat buatan yang baik adalah pada pinggiran atau tanggul pada areal pertanian. (Sakir dkk, 2018).

Manfaat dari menanam tanaman refugia di area pertanaman pokok antara lain : mikrohabitat yang diharapkan mampu memberikan kontribusi dalam usaha konservasi musuh alami, sumber nektar atau pakan bagi musuh alami sebelum adanya populasi hama di pertanaman, terciptanya agroekosistem yang seimbang, dimana jumlah hama yang ada dapat ditekan oleh keberadaan musuh alaminya, sehingga tidak menimbulkan kerugian secara ekonomi (di bawah ambang batas ekonomi). sebaiknya tanaman refugia ditanam sebelum tanaman utama agar dapat dimanfaatkan sebagai tempat berlindung dan berkembang biak bagi musuh alami dan serangga pollinator yang berperan dalam polinasi yaitu perantara penyerbukan tanaman (Wardana, 2017).

Tumbuhan berbunga menarik kedatangan serangga menggunakan karakter morfologi dan fisiologi dari bunga, yaitu ukuran, bentuk, warna, keharuman, periode berbunga, serta kandungan nektar dan polen. Kebanyakan dari serangga lebih menyukai bunga yang berukuran kecil, cenderung terbuka, dengan waktu berbunga yang cukup lama yang biasanya terdapat pada bunga dari famili Compositae atau Asteraceae. Bau atau aroma bunga juga menjadi daya tarik sekaligus tanda pengenal jenis tumbuhan bagi serangga. Aroma merupakan salah satu kemampuan adaptasi dari tanaman yang dapat bersifat sebagai penarik atau penolak. Bagi serangga polinator, bau atau aroma bunga lebih sulit dikenali dibandingkan dengan warna dari suatu bunga (Wardana, 2017).

bunga pacar air (Impaties balsamina) adalah tanaman tahunan atau dua tahunan dan memiliki bunga yang berwarna putih, merah, ungu, atau merah jambu. Bentuk bunganya menyerupai bunga anggrek yang kecil . Tinggi tanaman ini bias mencapai satu meter dengan batangnya yang tebal namun tidak mengayu dan daunnya yang bergerigi tepinya.

Komposisi terdiri dari ekstrak bunga bunga pacar air mengandung cyanidin, anthocyanin, delphinidin, malvidin, pelargonidin, quercetin, dan kaempherol. Manfaat tanaman ini sangat disukai lebah dan serangga lain yang membantu penyerbukannya. Walaupun demikian, tanaman ini tidak dapat hidup di lingkungan yang kering. Berbagai bagian tanaman ini biasa digunakan sebagai obat tradisional. Meningkatkan Populasi parasitoid telur wereng Anagirus nilaparvate (Syamsuardi, 2012).

Bunga bunga kertas (Zinnia peruviana) Berwarna mencolok dan beraneka warna seperti putih, kuning, 
oranye, merah, merah jambu, ungu dan lilac. Bunga nya selalu mekar sepanjang hari. Regenerasi tanaman tergolong cepat selama ketersediaan air terpenuhi. Tinggi tanaman $15 \mathrm{~cm}$ hingga 1 meter. Komposisi bunga: memiliki mahkota bunga yang sangat tipis dan kaku mirip dengan lembaran bunga kertas. Kelopaknya ada yang berlapis dan ada yang tidak. Manfaat bunga: sebagai refugia karena bentuk kelopaknya yang terbuka lebars ehingga banyak dikunjungi serangga dari berbagai jenis kupu-kupu, semut, kumbang, labalaba dan lebah (Purnawati, 2020).

Tujuan penelitian adalah untuk membandingkan pemanfaatan tanaman refugia dan tanpa refugia mengendalikan hama padi merah Natabo ramah lingkungan di Dusun Soporaru, Desa Sigotom Julu, Kecamatan Pangaribuan, Kabupaten Tapanuli Utara, Provinsi Sumatera Utara.

\section{METODE PENELITIAN Alat dan Bahan}

Bahan-bahan yang digunakan dalam penelitian ini adalah bibit padi merah Natabo, tanaman refugia bunga kenikir (Cosmos caudatus), bunga morning glory (Ipomoea purpurea), bunga pacar air (Impatiens balsamina), bunga bunga kertas (Zinnia peruviana).

Alat-alat yang digunakan dalam penelitian ini adalah buku, pinset, sarung tangan, pisau, botol film, polybag, perangkap warna putih, jaring serangga (sweep net), perangkap jatuh (pitfall trap), kamera, mikroskop, lup, kalkulator, buku kunci identifikasi serangga dari Henrichs (1995), Borror dkk. (1992), Shepard dkk (2011) dan IRRI (1994).

Metode penelitian yang digunakan adalah metode purposive sampling. Pengamatan dilakukan pada lahan pertanaman padi merah Natabo yang terbagi menjadi $100 \mathrm{~m}^{2}$ ditanami beberapa jenis refugia kemudian $100 \mathrm{~m}^{2}$ tanpa refugia. Pada setiap petakan diletakkan 3 jenis perangkap yang terdiri dari perangkap jarring (sweep net), 5 buah perangkap kuning (yellow trap) yang di pasang pada ke empat sisi lahan dan bagian tengah lahan dan 4 buah perangkap jatuh (pitfall trap) yang di pasang pada ke empat sisi lahan. Pengamatan dilakukan pada lahan pertanaman sebanyak 5 kali pada masa vegetatif dan 5 kali pada masa generatif.

\section{Pengadaan Tanaman refugia}

Penanaman tanaman refugia dimulai dari persemaian benih bunga bunga kenikir (Cosmos caudatus), bunga morning glory (Ipomoea purpurea), bunga pacar air (Impatiens balsamina), Bunga bunga kertas (Zinnia peruviana) pada polibag kecil yang di semaikan sebelum pengolahan lahan. Kemudian setelah selesai pengolahan lahan, bibit bunga tersebut di pindah tanam ke lahan, tepatnya pada bagian pinggir lahan (gadu). Setiap satu jenis bunga di tanam pada 1 sisi lahan secara merata. Bunga di pada pagi dan sore hari apabila tidak turun hujan.

\section{Penanaman padi merah Natabo}

Masing-masing lahan seluas $100 \mathrm{~m}^{2}$ di bersihkan dari batang padi sisa pertanaman sebelumnya. Kemudian lahan diolah dan di bajak dengan menggunakan cangkul. Sebelumnya dilakukan penyemaian padi merah Natabo varietas lokal yakni Sikasumbu 6 bulan yang di rendam dalam air selama 2 hari dua malam. Setelah lahan persemaian selesai, benih padi yang di rendam tadi di sebarkan secara merata pada lahan persemaian, dan kemudia ditutup jaring pada sekeliling lahan persemaian tadi guna menghindari hama burung dan tikus. Pindah tanam dilakukan pada \pm 40 hari setelah semai. Padi ditanam pada lahan padi dengan jarak tanam $25 \times 30 \mathrm{~cm}$.

Serangga yang tertangkap dari lapangan ada yang dapat di identifikasi 
secara langsung dan ada yang belum dapat diidentifikasi secara langsung. Serangga yang belum teridentifikasi secara langsung selanjutnya dibawa ke Laboratorium Hama Tumbuhan, Fakultas Pertanian, Universitas Sumatera Utara untuk dilakukan identifikasi. Identifikasi dilakukan sampai pada tingkat genus dengan menggunakan buku identifikasi dari Heinrichs (1995), Borror dkk. (1992), Shepard dkk (2011) dan IRRI (1994). Serangga yang tertangkap kemudian di foto dan dibuat koleksi.

Dari penelitian yang telah dilakukan, didapatkan data status peran arthropoda di kedua lahan mengalami keseimbangan ekosistem dikarenakan pada kedua lahan yaitu padi merah Natabo dengan refugia dan padi merah Natabo tanpa refugia mendapatkan jenis selain herbivor atau hama, yaitu kelompok arthropoda lain seperti predator, scavenger, polinator hingga parasitoid.

\section{HASIL}

Dari hasil penelitian yang telah dilakukan, sebanyak 10 kali pengambilan (5 kali pada fase vegetati dan 5 kali pada fase generatif) pada lahan refugia dan lahan tanpa refugia diperoleh komposisi serangga yang tertangkap dan teridentifikasi seperti tersaji pada Tabel 1 .

Tabel 1. Komposisi dan jumlah serangga tertangkap pada lahan refugia dan tanpa refugia. R=refugia, $\mathrm{TR}=$ Tanpa refugia

\begin{tabular}{|c|c|c|c|}
\hline \multirow[b]{2}{*}{ Ordo } & \multirow[b]{2}{*}{ Famili } & \multicolumn{2}{|c|}{ Total } \\
\hline & & $\mathrm{R}$ & TR \\
\hline \multirow{3}{*}{ Araneae } & Tetragonidae & 99 & 35 \\
\hline & Linyphiidae & 43 & 5 \\
\hline & Thomosidae & 71 & 10 \\
\hline \multirow{4}{*}{ Coleoptera } & Coccinellidae & 116 & 32 \\
\hline & Leiodidae & 20 & 0 \\
\hline & Staphilinidae & 43 & 1 \\
\hline & Dermestidae & 17 & 11 \\
\hline \multirow{4}{*}{ Diptera } & Phoridae & 66 & 27 \\
\hline & Tachinidae & 18 & 21 \\
\hline & Mucidae & 46 & 21 \\
\hline & Tipulidae & 22 & 39 \\
\hline \multirow{4}{*}{ Hemiptera } & Alydidae & 43 & 76 \\
\hline & Pentatomidae & 101 & 94 \\
\hline & Lygaeidae & 139 & 55 \\
\hline & Pyralidae & 72 & 204 \\
\hline \multirow{2}{*}{ Homoptera } & Cicadellidae & 46 & 74 \\
\hline & Dephacidae & 10 & 28 \\
\hline Hymenoptera & Formicidae & 271 & 102 \\
\hline \multirow{3}{*}{ Odonoata } & Gomphidae & 47 & 33 \\
\hline & Aeshnidae & 66 & 60 \\
\hline & Coenagrioidae & 99 & 83 \\
\hline \multirow[t]{2}{*}{ Orthoptera } & Acrididae & 480 & 785 \\
\hline & Gryllidae & 17 & 11 \\
\hline \multicolumn{2}{|c|}{ Total } & 1952 & 1807 \\
\hline
\end{tabular}

Dari hasil penelitian yang dilakukan dengan 10 kali pengambilan di lahan padi dengan pemanfaatan refugia diidentifikasi ada 8 ordo serangga dan 23 famili serangga yang tertangkap dengan 1952 populasi seranngga, sedangkan pada lahan 
padi tanpa pemanfaatan refugia terdapat 8 ordo serangga dan 22 famili serangga dengan 1806 populasi serangga. Ordo dengan populasi paling tinggi pada lahan dengan pemanfaatan refugia adalah ordo Orthoptera dengan jumlah populasi 497 ekor. Jumlah ini berbeda dengan penelitian Sianipar (2015) di Desa Sukawening, Kecamatan Ciwidey, Kabupaten Bandung, ordo Orthoptera yang tertangkap pada lahan padi dengan refugia yang hanya berjumlah 64 ekor serangga.

Hal ini berbeda dari penelitian sebelumnya yang dilakukan oleh Siregar dan Mukhtar (2018) menggunakan 3 perangkap yakni yelow trap, sweep net dan core sampler di Percut Seituan, dimana pada penelitian tersebut diidentifikasi ordo Orthoptera, famili Acrididae sebanyak 7 ekor, jumlah yang jauh lebih rendah dibandingkan pada lahan kontrol dipenelitian ini yakni 90 ekor serangga.

Jumlah serangga yang tertangkap pada kedua lahan berbeda. Dan jumlah populasi serangga yang tertangkap pada lahan padi dengan pemanfatan refugia adalah 1952 ekor. Angka ini lebih tinggi dibanding dengan jumlah serangga yang tertangkap pada lahan tanpa refugia yang berjumlah 1806 ekor. Hal ini diduga karena dengan adanya tanaman refugia yang ditanam dilahan padi menyebabkan ketersediaan makanan dan tempat berlindung dan berkopulasi bagi serangga. Seperti pada penelitian sebelumnya yang di lakukan oleh Bangun (2021) di Desa Batu Karang, Kecamatan Payung, Kabupaten Karo diperolah jumlah arthropoda pada lahan dengan pemanfaatan refugia sebanyak 2923 ekor, sedang pada lahan tanpa refugia lebih rendah yakni 2667 ekor serangga menggunakan perangkap transparant (transparent sticky trap), perangkap jaring (sweep net) perangkap kuning (yellow trap) dan perangkap jatuh (Pitfall trap). Faktor yang menyebabkan perbedaan jumlah arthropoda tertangkap didasarkan pada jumlah jenis refugia yang digunakan dan penggunaan empat perangkap.

Penggunaan 4 jenis refugia sebagai tanaman pinggiran lahan padi merah Natabo yaitu bunga kenikir (Cosmos caudatus), bunga bunga kertas (Zinnia peruviana), bunga pacar air (Impatiens balsamina) dan bunga morning glory (Ipomoea purpurea) didasarkan pada warna bunga yang mencolok pada tiap bunga dan ketersediaan tanaman pada daerah penelitian. Penggunaan refugia ini diasumsikan dapat memikat hama maupun musuh alami sehingga pada lahan padi merah Natabo.

Menurut Wardana dkk (2017) menyatakan bahwa tanaman refugia bukan hanya menjadi mikro habitat bagi musuh alami tetapi juga menarik hama karena warna yang mencolok dan aroma yang dihasilkan pada refugia dapat memikat hama. Hal ini karena warna dapat mempengaruhi spektrum penglihatan serangga. refugia dapat menarik kedatangan serangga menggunakan karakter 24 morfologi dan fisiologi yang dimiliki seperti ukuran, bentuk, warna, aroma, periode berbunga, maupun kandungan nektar dan polen.

Jumlah serangga yang tertangkap pada kedua lahan diduga juga dipengaruhi oleh iklim lingkungan sekitara lahan, diantaranya adalah kelembapan. Seperti pada literatur Wardani (2016) dinyatakan bahwa kelembaban udara mempengaruhi kehidupan serangga langsung atau tidak langsung. Serangga yang hidup di lingkungan yang kering mempunyai cara tersendiri untuk mengenfisienkan penggunaan air seperti menyerap kembali air yang terdapat pada feses yang akan dibuang dan menggunakan kembali air metabolik tersebut, contohnya serangga rayap. Oleh karena itu kelembaban harus dilihat sebagai keadaan lingkungan dan kelembaban sebagai bahan yang dibutuhkan organisme untuk 
melangsungkan proses fisiologis dalam tubuh. Sebagai unsur lingkungan, kelembaban sangat menonjol sebagai faktor modifikasi suhu lewat reduksi evapotranspirasi.

Selain kelembapan, jumlah serangga yang ditangkap pada penelitian ini juga dipengaruhi oleh curah hujan. Hal ini didukung oleh pendapat Wardani (2016) yang menyatakan bahwa Hujan secara langsung dapat mempengaruhi populasi serangga hama apabila hujan besar serangga hama banyak yang mati, berpengaruh terutama pada pertumbuhan dan keaktifan serangga. Unsur yang penting dalam analisis hujan adalah curah hujan, jumlah hari dan kelebatan hujan.

Dari hasil penelitian yang dilakukan diperoleh indeks biologi terdirri dari: indeks keanekaragaman $\left(\mathrm{H}^{\prime}\right)$, indeks kekayaan jenis $(\mathrm{R})$ dan indeks kemerataan jenis (E) seperti tersaji pada Gambar 1.

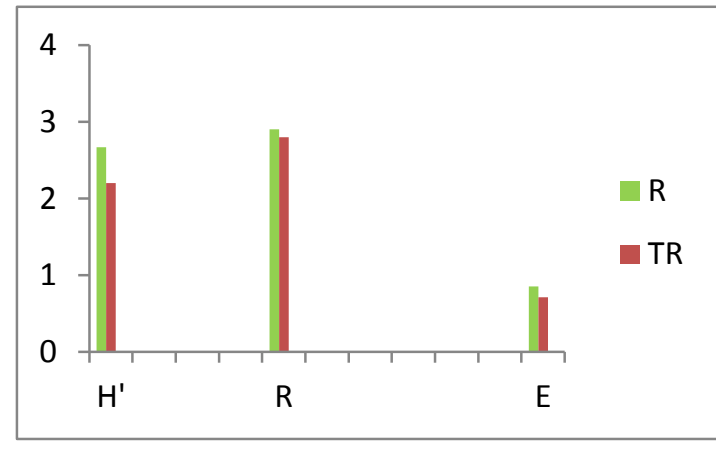

Gambar 1. Indeks biologi (keanekaragaman, Kekayaan dan Kemerataan Jenis).

Dari penelitian yang telah dilakukan diperoleh nilai indeks keanekaragaman serangga yang tertangkap pada penelitian ini di lahan padi merah Natabo dengan refugia adalah $\mathrm{H}^{\prime}=2,67$, dimana nilai ini menunjukkan bahwa keanekaragaman serangga pada lahan dengan refugia memiliki nilai sedang., demikian juga pada lahan tanpa refugia nilai indeks keanekaragaman serangga memiliki nilai $\mathrm{H}^{\prime}=2,19$ dan merupakan kriteria sedang.

Hasil perhitungan indeks keanekargaman serangga dalam kondisi lingkungan sedang dimana nila $H^{\prime}=2,84$ sedang disini berarti mengarah kedalam kondisi baik. Kriteria ini menunjukkan adanya keragaman hama dan musuh alami pada lahan padi yang akan saling meningkat jumlah populasinya menuju keseimbangan. Nilai indeks keanekaragaman serangga pada lahan padi merah Natabo dengan refugia pada penelitian ini lebih tinggi dari pada nilai indeks keanekaragaman yang diperoleh pada penelitian Bangun (2021) yang dilaksanakan di Desa Batu Karang, kecamatan Payung, Kabupaten Karo dengan menggunakan 4 jenis tanaman refugia dengan nilai indeks keanekaragaman serangga yang diperoleh adalah 2,371, perbedaan nilai tersebut diduga dipengaruhi oleh faktor berupa faktor biotik seperti makanan tersedia dan abiotik berupa suhu, curah hujan dan kelembapa yang berbeda.

Dari penelitian yang telah dilakukan, penyebab tidak berbeda jauhnya indeks keanekaragaman pada lahan padi merah Natabo refugia dan tanpa refugia dikarenakan jarak antar kedua lahan yang tidak terlalu jauh yang memungkinkan mobilitas arthropoda pada kedua nya. Penambahan refugia sebagai tanaman pinggir di satu lahan menyebabkan jumlah jenis individu yang lebih banyak dibandingkan dengan lahan 
tanpa refugia. Hal ini diakibatkan karena refugia memiliki fungsi sebagai tempat berlindung, perangkap dan penyedia makanan sehingga menjadi tempat tinggal arthropoda sekitar lahan terutama arthropoda yang berguna. Hal ini didukung oleh Siregar dan Matondang (2017) yang menyatakan jarak antara dua lahan yang berdekatan akan memiliki indeks komunitas yang sama.

Nilai kekayaan jenis yang dimiliki kedua lahan pengamatan dapat dilihat pada Gambar 1. Dimana pada lahan padi merah Natabo dengan refugia memiliki nilai kekayaan jenis sebesar 2,9 dan pada lahan tanpa refugia sebesar 2,8. Siregar (2015) menyatakan bahwa indeks kekayaan jenis yang disimbolkan dengan $\mathrm{R}$ dapat dihitung menggunakan rumus indeks kekayaan jenis margalef dimana Indeks kekayaan jenis (R) adalah jumlah total jenis dari suatu habitat dalam penelitian ini mmakai jumlah family yakni 23 family pada lahan refugia dan 22 family pada lahan tanpa refugia dikurang 1 dibagi dengan logaritma natural yang dikalikan dengan jumlah individu pada suatu habitat (1952 pada lahan refugia, dan 1807 pada lahan tanpa refugia).

Nilai kekayaan jenis kedua lahan ini termasuk dalam kategori yang sedang karena lebih besar dari 2,5 namun kurang dari 4. Margalef (1958) menyatakan bahwa kriteria kekayaan jenis terbagi 3 dimana $\mathrm{R}<2,5$ menunjukkan kekayaan jenis yang rendah, 2,5>R>4 menunjukkan kekayaan jenis yang sedang dan $\mathrm{R}>4$ menunjukkan kekayaan jenis yang tinggi.

Pada Gambar 1 terlihat jelas bahwa indeks kekayaan jenis pada lahan dengan refugia lebih tinggi dari lahan tanpa refugia. Dimana pada penelitian ini peneliti menanam 4 jenis tanaman refugia yakni bunga kenikir (Cosmos caudatus), bunga morning glory (Ipomoea purpurea), bunga pacar air (Impatiens balsamina), bunga kertas (Zinnia peruviana) di lahan padi merah Natabo dengan pemanfaatan refugia. Keberadaan keempat tanaman ini diduga menjadi salah satu faktor yang menyebabkan nilai indeks kekayaan jenis di kedua lahan berbeda.

Seperti literatur Wardana (2017) dijelaskan bahwa tumbuhan berbunga menarik kedatangan serangga menggunakan karakter morfologi dan fisiologi dari bunga, yaitu ukuran, bentuk, warna, keharuman, periode berbunga, serta kandungan nektar dan polen. Bau atau aroma bunga juga menjadi daya tarik sekaligus tanda pengenal jenis tumbuhan bagi serangga. Aroma merupakan salah satu kemampuan adaptasi dari tanaman yang dapat bersifat sebagai penarik atau penolak. Bagi serangga polinator, bau atau aroma bunga lebih sulit dikenali dibandingkan dengan warna dari suatu bunga.

Dari Penelitian yang telah dilakukan, diketahui nilai indeks kemerataan lahan (Evenness index) pada lahan padi merah Natabo dengan refugia dan tanpa tidak berbeda jauh, dimana nilai nya dapat di lihat pada Gambar 1. Indeks kemerataan lahan pada padi dengan refugia memiliki nilai $\mathrm{E}^{\prime}=0,85$ dan Indeks kemerataan lahan pada padi tanpa refugia dengan nilai $E^{\prime}=0,71$. Nilai indeks kemerataan di kedua lahan pengamatan ini termasuk dalam kategori tinggi. Hal ini sesuai dengan Odum (1996) yang menyatakan kriteria indeks kemerataan jenis terbagi 3 yaitu, $E^{\prime}<0,3$ menunjukkan kemerataan jenis yang termasuk dalam kategori rendah, $0,3>E^{\prime}>0,6$ menunjukkan kemerataan jenis yang termasuk dalam kategori sedang dan E'>0,6 menunjukkan kategori tinggi dimana maksimal indeks kemerataan jenis ini adalah 1 .

Pada gambar 1 terlihat nilai indeks kemerataan pada kedua lahan memiliki nilai yang tidak berbeda jauh antara lahan dengan refugia dan tanpa refugia, hal ini diduga karena jarak lahan yang tidak terlalu jauh, sehingga jenis dan jumlah 
serangga pada kedua lahan hampir sama serta iklim dari kedua lahan masih sama. Hal ini didukung dengan adanya penelitian trisnawati (2013) dengan judul "Pengaruh Habitat Termodifikasi Lahan Padi Sawah (Oryza Sativa) Menggunakan Trap Crop Terhadap Komposisi Dan Tingkat Keanekaragaman Arthropoda Herbivora" disitu ia menjelaskan bahwa tingginya nilai indeks kesamaan komunitas di kedua lahan disebabkan oleh lahan yang berdekatan, selain itu tipe habitat yang homogen hanya terdiri atas lahan padi sawah sehingga faktor yang ada pada lahan main crop juga ada pada lahan trap crop. Salah satunya adalah faktor tepi atau jarak kedua lahan yang hanya sekitar $50 \mathrm{~cm}$, padahal arthropoda yang terambil adalah arthropoda terbang yang mobilitasnya tinggi seperti acrididae yang lompatannya hampir mencapai 1 meter. Nilai kesamaan komunitas yang cukup tinggi dengan angka hampir mendakati satu maka sesuai dengan perhitungan untuk indeks keanekaragaman bahwa penggunaan trap crop sebagai modifikasi habitat tidak berpengaruh terhadap keanekaragaman Arhropoda Herbivora.

Nilai indeks kemerataan yang tinggi pada kedua lahan menunjukan tidak adanya salah satu family yang terlalu mendominasi pada kedua lahan. Hal ini didukung oleh Siregar (2015) yang menyatakan bahwa nilai E' berkisar antara 0-1. Nilai E' yang mendekati 0 menunjukan bahwa suatu jenis menjadi dominan dalam komunitas. Jika nilai E' mendekati 1, seluruh jenis memiliki tingkat kemerataan jenis yang hampir sama.

Makanan yang tersedia di lapangan menjadi salahsatu faktor pensukung kemerataan serangga di lapangan. Selain makanan, faktor iklim daerah sekitar lahan juga diduga menjadi faktor jumlah kemerataan serangga dikedua lahan penelitian. Hal ini didukung oleh penelitian sebelumnya yang dilakukan oleh Wardani (2016) dimana Faktor makanan sangat penting bagi kehidupan serangga hama. Keberadaan faktor makanan akan dipengaruhi oleh suhu, kelembaban, curah hujan dan tindakan manusia. Pada musim hujan, orang banyak menanam lahannya dengan berbagai tanaman. Apabila semua faktor lain sangat mendukung perkembangan serangga maka pertambahan populasi serangga akan sejalan dengan makin bertambahnya makanan. Keadaan sebaliknya akan menurunkan populasi serangga hama. Hubungan faktor makanan dengan populasi serangga itu disebut hubungan bertautan padat atau density independent.

Nilai kemerataan yang didapat pada penelitian ini lebih tinggi pada lahan padi dengan refugia dibanding pada lahan tanpa refugia. Hal ini diduga karena adanya tanaman bunga yang ditanaman pada sekitaran lahan mempengaruhi ketertarikan serangga untuk datang kelahan tersebut. Hal tersebut didukung oleh penelitian Sakir (2018) yang menyatakan bagi tanaman padi refugia dapat mendukung kegiatan konservasi sebagai pilihan dalam menjaga agroekosistem pada lahan pertanian refugia dengan warna mencolok merupakan tanaman yang mudah dibudidayakan sebagai tempat mikrohabitat serta organisme tertentu. Pada ekosistem lahan pertanian, keberadaan mikrohabitat buatan yang baik adalah pada pinggiran atau tanggul pada areal pertanian.

Dari penelitian yang telah dilakukan diperoleh ordo, family, serta status peran serangga pada lahan refugia dan tanpa refugia seperti pada Tabel 2 berikut ini. 
Tabel 2. Status fungsi serangga

\begin{tabular}{|c|c|c|c|c|}
\hline Ordo & Family & Status Peran Serangga & Dengan refugia & $\begin{array}{c}\text { Tanpa } \\
\text { refugia }\end{array}$ \\
\hline \multirow{3}{*}{ Araneae } & Tetragonidae & Predator & 99 & 35 \\
\hline & Linyphiidae & Predator & 43 & 5 \\
\hline & Thomosidae & Predator & 71 & 10 \\
\hline \multirow{4}{*}{ Coleoptera } & Coccinellidae & Predator & 116 & 32 \\
\hline & Leiodidae & Belum Diketahui & 20 & 0 \\
\hline & Staphilinidae & Predator & 43 & 1 \\
\hline & Dermestidae & Scavenger & 17 & 11 \\
\hline \multirow{4}{*}{ Diptera } & Phoridae & Parasitoid & 66 & 27 \\
\hline & Tachinidae & Parasitoid & 18 & 21 \\
\hline & Mucidae & Scavenger & 46 & 21 \\
\hline & Tipulidae & Herbivor & 22 & 39 \\
\hline \multirow{4}{*}{ Hemiptera } & Alydidae & Herbivor & 43 & 76 \\
\hline & Pentatomidae & Herbivor & 101 & 94 \\
\hline & Lygaeidae & Polinator & 139 & 55 \\
\hline & Flatidae & Herbivor & 72 & 204 \\
\hline \multirow{2}{*}{ Homoptera } & Cicadellidae & Herbivor & 46 & 74 \\
\hline & Dephacidae & Herbivor & 10 & 28 \\
\hline Hymenoptera & Formicidae & Predator & 271 & 102 \\
\hline \multirow{3}{*}{ Odonoata } & Gomphidae & Predator & 47 & 33 \\
\hline & Aeshnidae & Predator & 66 & 60 \\
\hline & Coenagrioidae & Predator & 99 & 83 \\
\hline \multirow{2}{*}{ Orthoptera } & Acrididae & Herbivor & 480 & 785 \\
\hline & Gryllidae & Scavenger & 17 & 11 \\
\hline & Total & & 1952 & 1807 \\
\hline
\end{tabular}

Pada tabel 2 terlihat jelas bahwa pada lahan refugia jumlah serangga yang berperan sebagai predator lebih tinggi dibandingkan pada lahan tanpa refugia. Predator adalah serangga atau hewan lain yang memakan serangga hama secara langsung Wardani (2016). Hal ini diduga karena adanya tanaman refugia salah satunya bunga bunga kertas menyebabkan peningkatan sumber pakan bagi serangga predator juga serangga hama. Seperti yang dijelaskan oleh Purnawati (2020) bahwa keberadaan tanaman Sebagai refugia karena bentuk kelopaknya yang terbuka lebars ehingga banyakd ikunjungi serangga dari berbagai jenis kupu-kupu, semut, kumbang, laba-laba dan lebah.

Tingginya jumlah serangga polinator dan parasioid pada lahan refugia di peneltian ini juga diduga karena adanya tanaman refugia salah satunya tanaman bunga pacar air disekitar

lahan menarik kehadiran serangga polinator (penyerbuk) dan serangga parasitoid. Hal ini di dukung oleh Syamsuardi (2012) yang menyatakan bahwa Tanaman ini sangat disukai lebah dan serangga lain yang membantu penyerbukannya. Walaupun demikian, tanaman ini tidak dapat hidup di lingkungan yang kering. Berbagai bagian tanaman ini biasa digunakan sebagai obat tradisional. Meningkatkan Populasi parasitoid telur wereng Anagirus nilaparvate.

Pada tabel 2 terlihat jumlah serangga hama pada penelitian ini lebih tinggi pada lahan tanpa refugia dibanding kan pada lahan tanpa refugia, hal ini diduga karena jumlah serangga predator 
yang rendah menyebabkan jumlah hama menigkat dibanding pada lahan dengan refugia yang memiliki jumlah predator lebih tinggi. Keberadaan predator dapat menurunkan populasi serangga hama dikarenakan serangga predator memangsa serangga hama secara langsung. Seperti yang dijelaskan Shara (2019) yang menyatakan bahwa Predator adalah binatang yang memakan hama/ OPT untuk memenuhi kebutuhan hidupnya. Berikut adalah contoh musuh alami dari golongan predator : Paedorus sp. atau dikenal dengan nama Tom-ket , merupakan predator dari hama kutu-kutuan, wereng, dan Myzus sp, Laba-laba sebagai pemangsa belalang dan hama tanaman yang lainnya seperti walang sangit dll.

Jumlah predator yang tertangkap pada penelitian ini lebih tinggi dilahan dengan refugia dibanding pada lahan tanpa refugia.jumlah musuh alamai yang tertangkap didominasi oleh predator yakni 855 ekor serangga predator. Hal ini serupa dengan penelitian yang dilakukan oleh Sumini (2020) dengan judul penelitian keanekaragaman dan kelimpahan musuh alami ditanaman padi berdasarkan jarak tanaman dengan tanaman refugia. Pada penelitian tersebut didapat jumlah musuh alami predator lebih tinggi daripada serangga musuh alami yang lain. Hal ini dikarenakan refugia menjadi tempat tinggal yang sesuai bagi serangga musuh alami terutama predator. Dari penelitian dan identifikasi yang dilakukan, diperoleh serangga dari kedua lahan penelitian dengan status fungsi yang dapat dilihat pada gambar berikut.
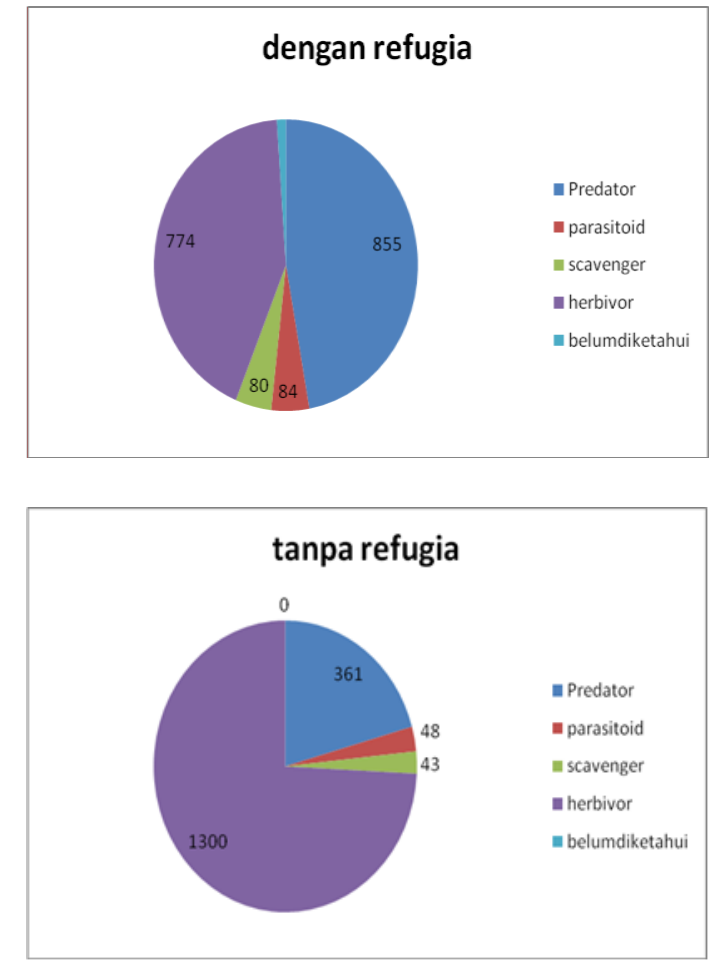

Gambar 2. diagram status fungsi serangga 


\section{KESIMPULAN}

Jumlah dan komposisi serangga tertangkap pada lahan refugia pada 10 kali pengambilan adalah 1952, sedang kan pada lahan tanpa refugia jumlah serangga tertangkap adalah 1807.

Pada lahan dengan refugia Nilai $\mathrm{R}=2,9, \mathrm{H}^{\prime}=2,67, \mathrm{E}=0,85$ dan pada lahan padi tanpa refugia $R=2,8, H^{\prime}=2,19$, dan $\mathrm{E}=0,71$

Status fungsi arthropoda pada lahan padi merah Natabo dengan refugia terbagi menjadi 5 kelompok yaitu Herbivor $=7$ famili ; 774 eko, Predator $=9$ famili; 855 ekor, Polinator $=1$ famili; 139 ekor, parasitoid $=2$ famili; 84 ekor dan Scavenger $=3$ famili; 80 ekor. Sedangkan pada lahan tanpa refugia terdiri dari Herbivor $=7$ famili; 1.300 ekor, Predator $=9$ famili; 361 ekor, Polinator $=1$ famili; 55 ekor, Parasitoid $=2$ famili; 48 ekor dan Scavenger $=3$ famili; 80 ekor.

\section{DAFTAR PUSTAKA}

Bangun Z., E. (2021). Keanekaragaman Arthropoda Pada Pertanaman Padi Merah (Oryza nivara L.) Dengan Refugia Dan Tanpa Refugia Di Desa Batu Karang, Kecamatan Payung, Kabupaten Karo. Medan: Agroteknologi, Universitas Sumatera Utara.

Erdiansyah, F. dan Putri, S. U. (2017). Optimalisasi Fungsi Bunga refugia Sebagai Pengendali Hama Tanaman Padi (Oryza sativa L.). Prosiding dari Seminar Nasional Hasil Penelitian 2017.

Erdiansyah, I., Ningrum, D. R. K., Damanhuri. (2018). Pemanfaatan Tanaman Bunga Marigold dan Kacang Hias Terhadap Populasi Arthropoda Pada Tanaman Padi Sawah. Journal of Applied
Agricultural Sciences, 2(2),118119.

Ihfitasari, T., Siregar, A. Z., Pinem, M. I. (2019). Indeks Kerapatan Mutlak, Kerapatan Relatif, Frekuensi Mutlak Dan Frekuensi Relatif Serangga Pada Tanaman Padi (Oryza sativa L.) Fase Vegetatif Dan Fase Generatif Di Percut, Sumatera Utara. Jurnal Online Agroekoteknologi, 7(2), 472-481.

Keppel, G., K.P. Van Niel, G.W. WardellJohnson, C.J. Yates, M.Byrne, L. Mucina, A.G.T. Schut, S.D. Hopper, dan S.E. Franklin. (2012). Refuge: Identifying and understanding safe havens for biodiversity under climate change. Global Ecology and Biogeography 21(4):393404.doi:10.1111/j.14668238.2011.00686.x

Odum, E. P. (1996). Dasar-Dasar Ekologi. Terjemahan Samingan, $\mathrm{T} \mathrm{J}$. Yogyakarta: Gadjah Mada University Press.

Purnawati, A., Didik, U.P., Rahmadini, N. (2020). Penerapan sistem pertanaman refugia sebagai mikrohabitat musuh alami pada tanaman padi. Jurnal Solma, 09 (01), 221-230.

Sakir, I. M. dan Desinta. (2018). Pemanfaatan refugia dalam meningkatkan produksi tanaman padi berbasis kearifan lokal. Jurnal Lahan Suboptimal, 7(1), 816.DOI:https://doi.org/10.33230/J LSO.7.1.2018.367

Sianipar. (2018). Fluktuasi Populasi Serangga Wereng Batang Coklat (Nilaparvata lugens) Pada Lahan Sawah Di Kabupaten Kerawang Jawa Barat. Bandung: Fakultas Pertanian, Universitas Padjajaran. 
Siregar, A. Z. (2015). Perhitungan Keanekaragaman Serangga. Medan: Universitas Sumatera Utara.

Siregar, A. Z. dan Matondang, I. R. (2017). Biodiversity insects used three traps of unpland rice fields in Simalungun District. International Journal of Scientific \& Technology Research, 6(2), 90-95. ISSN 22778616.

Siregar A.Z dan Mukhtar I. Pinem (2018). Keanekaragaman dan kelimpahan musuh alami ditanaman padi berdasarkan jarak dengan tanaman refugia. J. Agrotek Tropika, 8(1), 177 - 184. ISSN 2337-4993

Syamsuardi, Nadra Khairiah dan D.A. Helmi. (2012). Jenis-Jenis Serangga Pengunjung Bunga bunga pacar air (Impatiens balsamina Linn.: Balsaminaceae). Padang: Universitas Andalas.

Tarigan, E. (2019). Keanekaragaman serangga dan tingkat serangan hama walang sangit pada tanaman padi merah Natabo di Desa Sugihen, Kec. Juhar, Kab. Karo. Prodi Agroteknologi [skripsi]. Medan: Universitas Sumatera Utara.

Trisnawati I dan Najwa. (2013). Pengaruh Habitat Termodifikasi Lahan Padi Sawah (Oryza Sativa) Menggunakan Trap Crop Terhadap Komposisi Dan Tingkat Keanekaragaman Arthropoda Herbivora. Surabaya: Institut Teknolgi Sepuluh November.

Wardana, R., Erdiansyah, I., Putri, S. U. (2017). Presistensi hama (pemanfaatan tanaman refugia sebagai sistem pengendali hama padi) pada Kelompok Tani Surenjaya 01, Kecamatan Ledokombo. Prosiding Seminar Nasional Hasil Penelitian 2017.

Wardani, N. (2016). Perubahan Iklim dan Pengaruhnya Terhadap Serangga Hama. Bandar Lampung: Balai Pengkajian Teknologi Pertanian Lampung. 